\title{
Kajian Timbulan dan Komposisi Sampah di Kampus Institut Teknologi Nasional Bandung (Itenas)
}

\section{Study of Waste Generation and Composition in Bandung National Institute of Technology Campus (Itenas)}

\author{
GEANY SHARAH GUMILAR, SITI AINUN \\ Jurusan Teknik Lingkungan, Fakultas Teknik Sipil dan Perencanaan, Institut Teknologi Nasional, Bandung \\ Jalan PKH. Mustopha No. 23, Bandung \\ E-mail: geanysharahgumilar@gmail.com
}

\begin{abstract}
Educational institutions are places to conduct research and innovation to improve the quality of an independent environment. This study aims to determine the amount of waste generation and composition of institutions, especially the Bandung National Institute of Technology (Itenas). The sampling method is based on SNI 19-3964-1994 by measuring the production and composition of waste for eight consecutive days. The study results obtained an average generation of Itenas waste of $0.015 \mathrm{~kg} / \mathrm{m}^{2} / \mathrm{day}$ or 0.156 $\mathrm{kg} / \mathrm{person} /$ day in units of weight and $0.242 \mathrm{liters} / \mathrm{m}^{2} /$ day or 2.446 liters/person/day in units of volume. The composition of Itenas waste is dominated by organic waste by $50.78 \%$, which consists of food scraps and leaves, while other waste compositions include $14.09 \%$ plastic; $4.54 \%$ cardboard; $2.33 \%$ paper; $1.93 \%$ fabric; $1.21 \%$ glass; $0.08 \%$ cans; $0.03 \%$ metal and $24.99 \%$ residue or other waste. The highest activities that produce organic waste in Itenas are canteen activities, while the student center (SC) activities make the highest amount of recyclable waste.
\end{abstract}

Keywords: institutional solid waste, solid waste generation, waste composition, Bandung National Institution of Technology (Itenas)

\begin{abstract}
ABSTRAK
Institusi pendidikan adalah tempat untuk melakukan penelitian dan inovasi untuk meningkatkan kualitas lingkungan yang mandiri. Penelitian ini bertujuan untuk menentukan besaran timbulan dan komposisi sampah dari institusi khususnya Institut Teknologi Nasional Bandung (Itenas). Metode sampling yang dilakukan berdasarkan SNI 19-3964-1994 dengan cara melakukan pengukuran timbulan dan komposisi sampah selama 8 hari berturut-turut. Berdasarkan hasil penelitian diperoleh rata-rata timbulan sampah Itenas sebesar $0,015 \mathrm{~kg} / \mathrm{m}^{2} / \mathrm{hari}$ atau $0,156 \mathrm{~kg} / \mathrm{orang} / \mathrm{hari}$ dalam satuan berat dan $0,242 \mathrm{liter} / \mathrm{m}^{2} / \mathrm{hari}$ atau 2,446 liter/orang/hari dalam satuan volume. Komposisi sampah Itenas didominasi oleh sampah organik sebesar $50,78 \%$ yang terdiri dari sisa makanan dan dedaunan, sedangkan komposisi sampah lainnya antara lain $14,09 \%$ plastik; $4,54 \%$ kardus; $2,33 \%$ kertas; $1,93 \%$ kain; $1,21 \%$ kaca; $0,08 \%$ kaleng; $0,03 \%$ logam, dan $24,99 \%$ residu atau sampah lainnya. Kegiatan yang paling tinggi menghasilkan sampah organik di Itenas adalah kegiatan kantin sedangkan kegiatan student center (SC) menghasilkan sampah daur ulang yang paling tinggi.
\end{abstract}

Kata kunci: sampah institusi, timbulan sampah, komposisi sampah, Institut Teknologi Nasional Bandung (Itenas)

\section{PENDAhULUAN}

\subsection{Latar Belakang}

Menurut Undang-Undang No. 18 tahun 2008 tentang Pengelolaan Sampah ${ }^{(1)}$, sampah adalah sisa kegiatan sehari-hari manusia dan/ atau proses alam yang berbentuk padat. Sampah merupakan salah satu hal yang tidak terlepas dari kegiatan sehari-hari manusia seperti kegiatan domestik, institusi, perkantoran, perdagangan, dan industri. Institusi pendidikan tinggi adalah tempat untuk melakukan penelitian, dan inovasi untuk meningkatkan kualitas lingkungan yang mandiri. Sejak didirikan pada abad ke-20, lembaga pendidikan tinggi di Indonesia telah memainkan peran penting dalam membentuk dan memberdayakan masyarakat. Menurut Direktorat Jenderal Pendidikan Tinggi Indonesia - DIKTI, 3.293 lembaga pendidikan tinggi, terdiri atas 122 lembaga publik dan 3.171 lembaga swasta(2). Angka-angka tersebut menunjukkan bahwa institusi pendidikan tinggi swasta memiliki potensi besar dalam menangani masalah lingkungan. Masalah lingkungan di lingkungan kampus dapat berkurang dengan menerapkan 
program green campus. Green campus merupakan program yang telah diterapkan secara global mengenai pendidikan lingkungan untuk mengatur pendidikan kampus yang berbasis lingkungan, inovasi, dan penelitian dari departemen akademik serta menerapkannya pada manajemen sehari-hari di kampus ${ }^{(3)}$. Itenas belum mengikuti program green campus sehingga diperlukannya data terkait besaran timbulan dan komposisi sampah di Itenas untuk merencanakan program green campus yang dapat diterapkan di Itenas. Oleh karena itu, kajian timbulan dan komposisi sampah di Itenas perlu dilakukan agar dapat membantu dalam merencanakan sistem pengelolaan sampah yang berbasis lingkungan di Itenas.

Berdasarkan penelitian yang dilakukan di University of Northen British Columbia, Kanada memperlihatkan bahwa komposisi sampah terdiri atas beragam jenis material yang berasal dari sumber yang berbeda-beda seperti ruang kelas, laboratorium, area administrasi, kafetaria, pusat kesehatan, dan lain sebagainya ${ }^{(4)}$. Salah satu tempat yang berpotensi menghasilkan sampah dalam suatu kota adalah kampus yang memiliki aktivitas rutin, bahkan di hari libur, tentu terdapat berbagai jenis sampah setiap harinya ${ }^{(5)}$. Menurut Kahmeyer et $\mathrm{al}^{(6)}$, meskipun banyak kampus memiliki gambaran kasar mengenai jumlah limbah yang dihasilkan, sedikit informasi yang ada mengenai karakter aktual dan komposisi limbah yang timbul. Smyth et al ${ }^{(7)}$ mencatat bahwa meskipun kegiatan di sebagian besar kampus tampak sama sepanjang tahun, pada kenyataannya dapat terjadi perbedaan dalam hal jumlah siswa dan limbah yang timbul. Selain itu, komposisi limbah mungkin berbeda tergantung pada musim(8)

Marhaban Lingga melakukan studi timbulan dan komposisi sampah kawasan kampus UIN Ar-Raniry pada tahun $2019^{(9)}$. Satu output dari penelitian adalah rincian komposisi dari limbah yang dihasilkan, studi tersebut menemukan bahwa sebanyak 50,66\% sampah organik yang terdiri atas sampah kertas 20,99\%, sampah makanan $19,83 \%$, sampah halaman $6,43 \%$, dan sampah kayu 3,14\%, sedangkan sampah anorganik yang terdiri atas sampah plastik $25,50 \%$, kaleng $16,43 \%$, kaca $3,11 \%$, dan tekstil $0,48 \%{ }^{(9)}$. Berdasarkan hal tersebut maka diperlukan upaya pemanfaatan sampah antara lain melakukan pembuatan kompos (sampah sisa organik, sayur-sayuran, buah-buahan, rumput, serbuk kayu, nasi, dan sebagainya), menerapkan sistem bank sampah di UIN ArRaniry, serta melakukan proses daur ulang

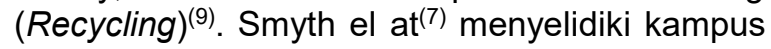
Prince George di University of Northern British Columbia (UNBC) dan menemukan bahwa lebih dari $70 \%$ (berat) sampah dapat dialihkan melalui pengurangan limbah, daur ulang dan pengomposan.

Zhang et al(10) melakukan studi lain di University of Southampton, Inggris, yang menemukan bahwa menempatkan wadah sampah daur ulang di dapur dari gedung universitas mengingkatkan laju daur ulang dengan rerata $25 \%$ dengan tingkat kontaminasi terendah, mendukung teori bahwa program daur ulang yang sukses memerlukan infrastruktur yang dirancang dengan cermat dan nyaman. Berdasarkan hal tersebut, pengelolaan limbah dapat diidentifikasi, diperkuat, dan dikembangkan secara bertahap dengan cara yang berkelanjutan dengan mempertimbangkan faktor politik, ekonomi, sosial, teknis, hukum dan lingkungan, hirarki limbah dan infrastruktur, layanan pengadaan serta perubahan perilaku(10) Mason et al(11) juga menemukan bahwa penerapan pemisahan wadah di dapur dan daerah kafetaria di kampus Turitea, University Massey, Selandia Baru, meningkatkan tingkat daur ulang dan pengomposan menjadi $88 \%$. Berdasarkan kajian yang dilakukan oleh Taghizadeh et $\mathrm{al}^{(8)}$, bahwa lebih dari $80 \%$ dari sampah yang dihasilkan di Universitas Tabriz, Iran, dapat dialihkan melalui pengurangan limbah, daur ulang dan pengomposan. Sampah organik merupakan komponen sampah yang paling penting (1.399,8 kg dari $2.500 \mathrm{~kg}$ sampah yang dihasilkan setiap hari) sehingga penulis mendirikan sebuah studi kelayakan untuk menghasilkan kompos dari sampah organik dalam kampus( ${ }^{(18)}$. Temuan tersebut menguatkan penemuan dari Salami et $a^{(12)}$ Forouhar dan Hristovski(13), dan Kalanatarifard \& Yang ${ }^{(14)}$, yang menjelaskan bahwa persentase yang tinggi dari sampah organik adalah sampah yang umumnya dihasilkan oleh negara berkembang.

\subsection{Tujuan}

Tujuan dari penelitian ini adalah untuk menentukan timbulan dan komposisi sampah dari kampus Institut Teknologi Nasional (Itenas). Hasil penelitian ini diharapkan dapat menjadi bahan pertimbangan dalam merencanakan sistem pengelolaan sampah di Itenas, serta menjadi sumber informasi bagi data kuantitas dan kualitas sampah di suatu insitusi pendidikan tinggi di Indonesia.

\section{BAHAN DAN METODE}

\subsection{Bahan dan Peralatan}

Bahan dan peralatan yang digunakan dalam penelitian ini, meliputi: (1) Sampel sampah setiap kegiatan/ aktivitas di Itenas; (2) Sampling Box ukuran $30 \mathrm{~cm}$ x $30 \mathrm{~cm} \times 40 \mathrm{~cm}$; (3) Timbangan gantung (crane scale) $50 \mathrm{~kg}$; (4) 
Terpal; (5) Trashbag; (6) Sarung Tangan; dan (7) Masker.

\subsection{Metode}

Penelitian ini dilakukan pada Oktober 2019 dengan melakukan pengukuran timbulan dan komposisi sampah yang dilakukan selama 8 hari berturut-turut yang mengacu pada SNI 19-39641994(15), metode pengumpulan data yang dilakukan dalam penelitian adalah sebagai berikut:

\section{a. Penentuan Titik Sampel}

Penentuan titik sampel ini didasarkan pada kegiatan di Itenas yang mempresentasikan komposisi dan karakteristik sampah. Kegiatan yang ada di Itenas antara lain perkuliahan, laboratorium, studio, administrasi, fasilitas umum, poliklinik, student centre (SC), ruang bersama (GSG) kantin, lapangan taman, parkiran, dan jalan.

b. Penentuan Jumlah Sampel dan Distribusi Sampel

Penentuan jumlah sampel yang diteliti dapat menggunakan metode slovin. Jumlah sampel yang ditentukan dihitung dengan rumus slovin yang disajikan pada persamaan $(1)^{(16)}$.

$$
n=\frac{N}{1+N e^{2}}
$$

Keterangan:

$$
\begin{array}{ll}
\mathrm{n} & \text { : jumlah sampel } \\
\mathrm{N} & \text { : jumlah populasi } \\
\mathrm{e} & \text { : batas toleransi kesalahan (error balance) }
\end{array}
$$

Tahap selanjutnya setelah mengumpulkan data antara lain pengolahan data timbulan sampah yang dilakukan dalam penelitian ini adalah sebagai berikut:

\section{Timbulan Sampah (q)}

Pengolahan data timbulan sampah memerlukan data berat sampah $(\mathrm{kg})$ dan volume (liter) dari pengukuran sampling timbulan sampah serta data luas sampel. Rerata satuan timbulan sampah sejenis rumah tangga dapat dihitung dengan menggunakan persamaan (2) ${ }^{(17)}$.

$$
q n s=\frac{(q A 1 \times \% P L A 1)+(q A 2 \times \% P L A 2)+\cdots(q A n \times \% P L A n)}{\% P L A 1+\% P L A 2+\cdots \% P L A n}
$$

\section{Keterangan:}

qns : satuan timbulan sampah non domestik/ sejenis rumah tangga $\left(\mathrm{L} / \mathrm{m}^{2} /\right.$ hari) atau $\left(\mathrm{kg} / \mathrm{m}^{2} /\right.$ hari $)$

qA1 : satuan timbulan sampah kegiatan $1\left(\mathrm{~L} / \mathrm{m}^{2} /\right.$ hari $)$ atau $\left(\mathrm{kg} / \mathrm{m}^{2} / \mathrm{hari}\right)$ q A2 : satuan timbulan sampah kegiatan $2\left(\mathrm{~L} / \mathrm{m}^{2} /\right.$ hari $)$ atau $\left(\mathrm{kg} / \mathrm{m}^{2} / \mathrm{hari}\right)$

q An : satuan timbulan sampah kegiatan $n\left(L / m^{2} / h a r i\right)$ atau $\left(\mathrm{kg} / \mathrm{m}^{2} / \mathrm{hari}\right)$

PLA : persen proporsi luasan sampel (\%)

Penentuan timbulan sampah (q) sejenis sampah rumah tangga berasal dari pengukuran sampling timbulan sampah di Itenas dengan 13 titik sampel berdasarkan kegiatan yang ada di Itenas. Hasil dari pengukuran timbulan sampah antara lain berat sampah dan volume sampah, untuk menghitung satuan timbulan sampah hasil berat sampah dan volume sampah dibagi dengan luasan tiap kegiatan. Setelah mendapatkan satuan timbulan sampah setiap kegiatan, maka tahap selanjutnya yaitu menghitung satuan timbulan sampah rerata dengan rumus persamaan (2).

\section{Total Timbulan Sampah}

Data total timbulan sampah digunakan untuk mengetahui timbulan sampah total yang ditimbulkan dalam suatu wilayah. Persamaan yang digunakan untuk menghitung total timbulan sampah dapat dilihat pada Persamaan $(3)^{(17)}$.

Qns $=$ qds $\times P$

Keterangan:

Qns : total timbulan sampah (L/hari) atau (kg/hari)

qns : satuan timbulan sampah sejenis rumah tangga/ non domestik ( $\mathrm{L} / \mathrm{m}^{2} /$ hari) atau $\left(\mathrm{kg} / \mathrm{m}^{2} /\right.$ hari)

$P \quad$ : jumlah total luas $\left(\mathrm{m}^{2}\right)$

\section{Persentase (\%) Komposisi Sampah}

Data persentase (\%) komposisi sampah dapat diketahui dengan mengetahui berat total sampah $(\mathrm{kg})$ dengan berat sampah dari setiap jenis sampahnya $(\mathrm{kg})$. Persentase $(\%)$ komposisi sampah dapat dihitung dengan menggunakan rumus Persamaan (4).

$\%$ Komposisi $=\frac{\text { Berat sampah sesuai dengan jenisnya }(\mathrm{kg})}{\text { Berat total sampah }(\mathrm{kg})} \times 100 \%$

\section{HASIL DAN PEMBAHASAN}

\subsection{Jumlah dan Distribusi Sampel di Itenas}

Itenas memiliki luas tanah sebesar $54.854 \mathrm{~m}^{2}$ yang terdiri atas luas lahan terbuka dan luas lantai. Namun, Itenas memiliki luas lahan terbangun sehingga jumlah sampel yang dihitung merupakan penjumlahan dari luas lahan terbangun dan luas lahan terbuka. Luas lahan terbangun dan luas lahan terbuka di Itenas berturut-turut sebesar $45.662 \mathrm{~m}^{2}$ dan $31.998 \mathrm{~m}^{2}$, sehingga jumlah sampel yang digunakan dalam kajian ini adalah sebesar $77.660 \mathrm{~m}^{2}$ yang dapat dilihat pada Tabel 1. Jumlah civitas akademika di 
Itenas antara lain sebanyak 7.212 orang yang terdiri atas mahasiswa, dosen serta karyawan disajikan pada Tabel 2 .

Hasil perhitungan jumlah sampel berdasarkan rumus slovin dengan batas toleransi $10 \%$ sehingga total luas wilayah yang akan diambil sampelnya adalah sebesar $1.189 \mathrm{~m}^{2}$ dengan distribusi sampel yang terpilih disajikan pada Tabel 2. Penentuan distribusi sampel yang dilakukan berdasarkan luas 1 (satu) gedung atau 1 (satu) area tertentu karena jika menggunakan rencana jumlah sampel yang telah dihitung maka akan sulit menentukan area mana yang harus di sampling pada saat melakukan pengumpulan sampah dari setiap titik sampling sehingga diperlukannya penyesuaian luas titik sampel dengan luas eksisting sehingga distribusi sampel dan luas wilayah titik sampling dapat diperhitungkan.
Tabel 1. Luas Itenas

\begin{tabular}{clcc}
\hline No. & Luas itenas & Luas $\left(\mathbf{m}^{2}\right)$ & Proporsi (\%) \\
\hline 1. & $\begin{array}{l}\text { Luas Lahan } \\
\text { Terbangun }\end{array}$ & 45.662 & 59 \\
\hline 2. & $\begin{array}{l}\text { Luas Lahan } \\
\text { Terbuka }\end{array}$ & 31.998 & 41 \\
\hline & Total & $\mathbf{7 7 . 6 6 0}$ & $\mathbf{1 0 0}$ \\
\hline
\end{tabular}

Tabel 2. Jumlah civitas akademika Itenas

No. Civitas akademika Jumlah (orang)

\begin{tabular}{rlc}
\hline 1. & Mahasiswa & 7.212 \\
\hline 2. & Dosen & 246 \\
\hline 3. & Karyawan & 237 \\
\hline & Total & $\mathbf{7 . 6 9 5}$
\end{tabular}

Sumber: Biro Akademik dan Administrasi Kemahasiswaan (BAAK) Itenas, 2019

Tabel 3. Distribusi sampel dan luas wilayah titik sampling

\begin{tabular}{|c|c|c|c|c|c|c|}
\hline No. & Kegiatan & $\begin{array}{c}\text { Rencana } \\
\text { jumlah sampel } \\
\left(\mathrm{m}^{2}\right)\end{array}$ & $\begin{array}{c}\text { e } \\
\text { (eror) }\end{array}$ & Titik sampel & $\begin{array}{c}\text { Realisasi luas } \\
\text { titik sampel } \\
\left(\mathrm{m}^{2}\right)\end{array}$ & e (eror) \\
\hline 1. & Laboratorium & 99 & $10 \%$ & $\begin{array}{l}\text { Gedung } 8 \text { Teknik } \\
\text { Lingkungan }\end{array}$ & 280 & $6 \%$ \\
\hline \multirow[t]{2}{*}{2.} & \multirow[t]{2}{*}{ Studio } & \multirow[t]{2}{*}{93} & \multirow[t]{2}{*}{$10 \%$} & $\begin{array}{l}\text { Gedung } 8 \text { Teknik } \\
\text { Planologi }\end{array}$ & 168 & \multirow[t]{2}{*}{$3 \%$} \\
\hline & & & & Gedung 1 Desain & 612 & \\
\hline 3. & Perkuliahan & 99 & $10 \%$ & Gedung 14 & 144 & $9 \%$ \\
\hline 4. & Lapangan & 93 & $10 \%$ & Lapangan Tenis & 250 & $6 \%$ \\
\hline 5. & Taman & 93 & $10 \%$ & Taman Batu & 140 & $8 \%$ \\
\hline 6. & Administrasi & 98 & $10 \%$ & Gedung 14 & 659,7 & $4 \%$ \\
\hline 7. & Fasilitas Umum & 95 & $10 \%$ & Masjid & 570 & $4 \%$ \\
\hline 8. & Poliklinik & 46 & $10 \%$ & Poliklinik & 84 & $1 \%$ \\
\hline 9. & Student Centre & 96 & $10 \%$ & Student Centre & 2.292 & $1 \%$ \\
\hline 10. & Ruang Bersama (GSG) & 92 & $10 \%$ & Ruang Bersama (GSG) & 1.200 & $1 \%$ \\
\hline 11. & Kantin & 88 & $10 \%$ & Kantin & 700 & $1 \%$ \\
\hline 12. & Jalan & 100 & $10 \%$ & $\begin{array}{l}\text { Jalan antara Parkir Gd. } \\
14 \text { dan Parkir } \\
\text { Lapangan Tenis }\end{array}$ & 100 & $10 \%$ \\
\hline 13. & Parkiran & 99 & $10 \%$ & Depan Kantin & 420 & $5 \%$ \\
\hline & Total & 1.189 & & & $7.618,7$ & \\
\hline
\end{tabular}

Sumber: Hasil Perhitungan, 2019; BKU Itenas, 2019

Berdasarkan Tabel 3, terlihat bahwa total sampel yang direncanakan dengan batas toleransi $10 \%$ adalah sebesar $1.189 \mathrm{~m}^{2}$. Namun, realisasi luas titik sampel berdasarkan luas eksisting dari titik sampel sehingga memperoleh total sampel sebesar $7.618,7 \mathrm{~m}^{2}$ dengan batas toleransi sebesar 1,1\%. Angka tersebut menunjukkan bahwa sampling yang telah dilakukan memiliki tingkat kepercayaan yang lebih tinggi dibandingkan perencanaan awal yaitu sebesar $98,9 \%$.

\subsection{Besaran Timbulan dan Densitas Sampah di Itenas}

Rata-rata timbulan sampah Itenas pada penelitan ini ditentukan berdasarkan rata-rata timbulan sampah dari masing-masing kegiatan yang ada di Itenas. Timbulan sampah yang dilakukan berdasarkan luas area kampus $\left(\mathrm{kg} / \mathrm{m}^{2} /\right.$ hari dan $\mathrm{L} / \mathrm{m}^{2} /$ hari) dan jumlah penghuni kampus (kg/orang/hari dan L/orang/hari). Timbulan sampah Itenas dalam satuan berat dan satuan volume setiap kegiatan di Itenas disajikan pada Tabel 4. 
Tabel 4. Rata-rata satuan timbulan sampah berdasarkan luas area Itenas

\begin{tabular}{|c|c|c|c|c|c|c|}
\hline \multirow{2}{*}{ Kegiatan } & \multirow{2}{*}{$\begin{array}{c}\begin{array}{c}\text { Luas area } \\
\text { total }\end{array} \\
\left(\mathrm{m}^{2}\right)\end{array}$} & \multirow{2}{*}{$\begin{array}{c}\text { Luas area } \\
\text { sampel }\end{array}$} & \multirow{2}{*}{$\begin{array}{c}\begin{array}{c}\text { Proporsi } \\
\text { luas }\end{array} \\
(\%)\end{array}$} & \multicolumn{2}{|c|}{ Timbulan sampah } & \multirow{2}{*}{$\begin{array}{c}\begin{array}{r}\text { Rata-rata } \\
\text { berat jenis }\end{array} \\
(\mathrm{kg} / \mathrm{L})\end{array}$} \\
\hline & & & & (kg/m²/hari) & (L/m²/hari) & \\
\hline Laboratorium & $8.136,4$ & 280 & 10,48 & 0,0004509 & 0,01178 & 0,038 \\
\hline Studio & 1.354 & 780 & 1,74 & 0,0004997 & 0,00520 & 0,096 \\
\hline Perkuliahan & $19.264,1$ & 144 & 24,81 & 0,0028326 & 0,06859 & 0,041 \\
\hline Lapangan & 1.250 & 250 & 1,61 & 0,0002496 & 0,00469 & 0,053 \\
\hline Taman & 1.245 & 140 & 1,60 & 0,0003679 & 0,00580 & 0,063 \\
\hline Administrasi & $4.169,7$ & 659,7 & 5,37 & 0,0003108 & 0,00791 & 0,039 \\
\hline Fasilitas Umum & 1.810 & 570 & 2,33 & 0,0003361 & 0,00503 & 0,067 \\
\hline Poliklinik & 84 & 84 & 16,48 & 0,0000037 & 0,00013 & 0,028 \\
\hline Student Centre & 2.292 & 2.292 & 0,11 & 0,0002329 & 0,00411 & 0,057 \\
\hline Ruang Bersama & 1.200 & 1.200 & 2,95 & 0,0000109 & 0,00142 & 0,008 \\
\hline Kantin & 700 & 700 & 1,55 & 0,0002495 & 0,00154 & 0,162 \\
\hline Jalan & 23.353 & 100 & 0,90 & 0,0078499 & 0,10296 & 0,076 \\
\hline Parkiran & 12.802 & 420 & 30,07 & 0,0020853 & 0,02329 & 0,089 \\
\hline
\end{tabular}

Tabel 5. Total timbulan sampah di Itenas

\begin{tabular}{|c|c|c|c|c|c|c|c|c|}
\hline \multicolumn{2}{|c|}{$\begin{array}{l}\text { Populasi total } \\
\text { Itenas }\end{array}$} & \multicolumn{3}{|c|}{ Timbulan dalam satuan berat } & \multicolumn{3}{|c|}{ Timbulan dalam satuan volume } & \multirow{2}{*}{$\begin{array}{c}\begin{array}{c}\text { Rata-rata } \\
\text { berat jenis }\end{array} \\
(\mathrm{kg} / \mathrm{L})\end{array}$} \\
\hline$\left(m^{2}\right)$ & (orang) & (kg/m²/hari) & (kg/org/hari) & (kg/hari) & (L/m²/hari) & (L/org/hari) & (L/hari) & \\
\hline 77.660 & 7.695 & 0,015 & 0,156 & $1.202,2$ & 0,242 & 2,480 & $18.828,1$ & 0,064 \\
\hline
\end{tabular}

Berdasarkan Tabel 4, rata-rata satuan timbulan sampah di Itenas sebesar 0,015 $\mathrm{kg} / \mathrm{m}^{2} /$ hari atau $0,242 \mathrm{~L} / \mathrm{m}^{2} /$ hari. Kegiatan yang memberikan kontribusi besar dalam satuan berat maupun volume yaitu kegiatan jalan yang menghasilkan sampah sebesar $0,0078 \mathrm{~kg} / \mathrm{m}^{2} / \mathrm{hari}$ dan $0,103 \mathrm{~L} / \mathrm{m}^{2} /$ hari sedangkan kegiatan poliklinik menghasilkan sampah paling sedikit sebesar $0,0000037 \mathrm{~kg} / \mathrm{m}^{2} /$ hari dan $0,00013 \mathrm{~L} / \mathrm{m}^{2} /$ hari. Hal tersebut disebabkan oleh tingginya kegiatan yang dilakukan di jalan dibandingkan di poliklinik sehingga berat sampah yang dihasilkan pada kegiatan jalan lebih banyak.

Setelah mengetahui rata-rata timbulan sampah dapat diperoleh timbulan sampah di Itenas dengan cara mengalikan satuan timbulan sampah satuan berat $\left(\mathrm{kg} / \mathrm{m}^{2} /\right.$ hari $)$ dan satuan volume $\left(\mathrm{L} / \mathrm{m}^{2} /\right.$ hari) dengan populasi total Itenas $\left(\mathrm{m}^{2}\right)$. Berdasarkan Tabel 5 terlihat bahwa timbulan sampah total yang dihasilkan di Itenas sebesar 18.828,1 L/hari atau 1.202,2 kg/hari dengan luas total area dan jumlah populasi di Itenas seluas $77.660 \mathrm{~m}^{2}$

Berdasarkan Tabel 5 terlihat bahwa timbulan sampah di Itenas menghasilkan sampah sebesar $0,156 \mathrm{~kg} / \mathrm{org} / \mathrm{hari}$ dan 2,446 L/org/hari. Menurut Tchobanoglous (1993)(18), besar timbulan sampah untuk institusi berkisar antara 0,08 kg/org/hari - 0,136 kg/org/hari, hal tersebut menunjukkan bahwa timbulan sampah di Itenas memiliki timbulan sampah yang lebih besar. Besarnya timbulan sampah tersebut didapatkan dari hasil pembagian nilai timbulan sampah Itenas yaitu $1.202,2 \mathrm{~kg} /$ hari dengan populasi total sebesar 7.695 orang dan jumlah pengunjung diluar data populasi total Itenas yang tidak terdata sehingga hasil timbulan sampah Itenas lebih besar.

Selain timbulan sampah, berdasarkan Tabel 5 dapat diketahui berat jenis sampah di Itenas sebesar 0,064 kg/L. Besarnya berat jenis sampah tersebut dapat dipengaruhi oleh berat dan volume sampah. Berat dan volume sampah tersebut dipengaruhi oleh jenis sampah yang paling dominan. Oleh karena itu jika dilihat berdasarkan kegiatan, berat jenis sampahnya akan berbeda-beda.

\subsection{Komposisi Sampah di Itenas}

Komposisi sampah atau jenis sampah yang dilakukan pada penelitian ini mengacu pada Peraturan Menteri Pekerjaan Umum No. 3 Tahun 2013 tentang Penyelenggaraan Prasarana dan Sarana Persampahan dalam Penanganan Sampah Rumah Tangga dan 
Sejenis Rumah Tangga(19). Berdasarkan hal tersebut jenis sampah yang diukur dikelompokkan menjadi 9 (sembilan) jenis sampah yang terdiri dari sampah organik (sisasisa makanan dan hasil proses alam), kertas, kardus, plastik, logam, kaleng, kaca, kain, serta residu (sampah bahan berbahaya dan beracun (B3), sampah yang telah terkontaminasi dengan makanan atau B3 atau sampah lainnya). Berdasarkan hasil pengukuran yang mengacu pada SNI 19-9364-1994(15), komposisi sampah yang dihasilkan di Itenas disajikan pada Gambar 1.

Berdasarkan pada Gambar 1 komposisi sampah yang paling dominan di Itenas antara lain sampah organik sebesar 50,78\% sedangkan sampah residu, plastik, kardus, kertas, kain, kaca, kaleng, dan logam berturutturut sebesar 24,99\%; 14,09\%; 4,54\%; 2,33\%; $1,93 \% ; 1,21 \% ; 0,08 \%$; dan 0,03\%. Komposisi sampah tersebut dapat dikelompokkan menjadi sampah organik, sampah yang dapat didaur ulang dan sampah residu. Komposisi sampah kertas di Itenas sangat kecil karena sebagian kegiatannya tidak banyak menggunakan kertas, misalnya pengumpulan tugas via email, materi perkuliahan yang berbentuk softfile, menggunakan kertas di kedua sisi untuk surat keterangan antar jurusan atau fakultas, dan adanya pengumpulan tersendiri untuk sampah kertas oleh setiap petugas gedung sehingga tidak masuk ke dalam wadah yang ada di setiap gedung.

Terdapat hasil perhitungan komposisi sampah sesuai dengan pengelompokan komposisi sampah berdasarkan kegiatan di Itenas yang disajikan pada Gambar 2, pengelompokan komposisi sampah tersebut antara lain sampah organik, sampah yang dapat didaur ulang (kertas, kardus, plastik, logam, kaleng, kaca, dan kain), dan sampah residu.

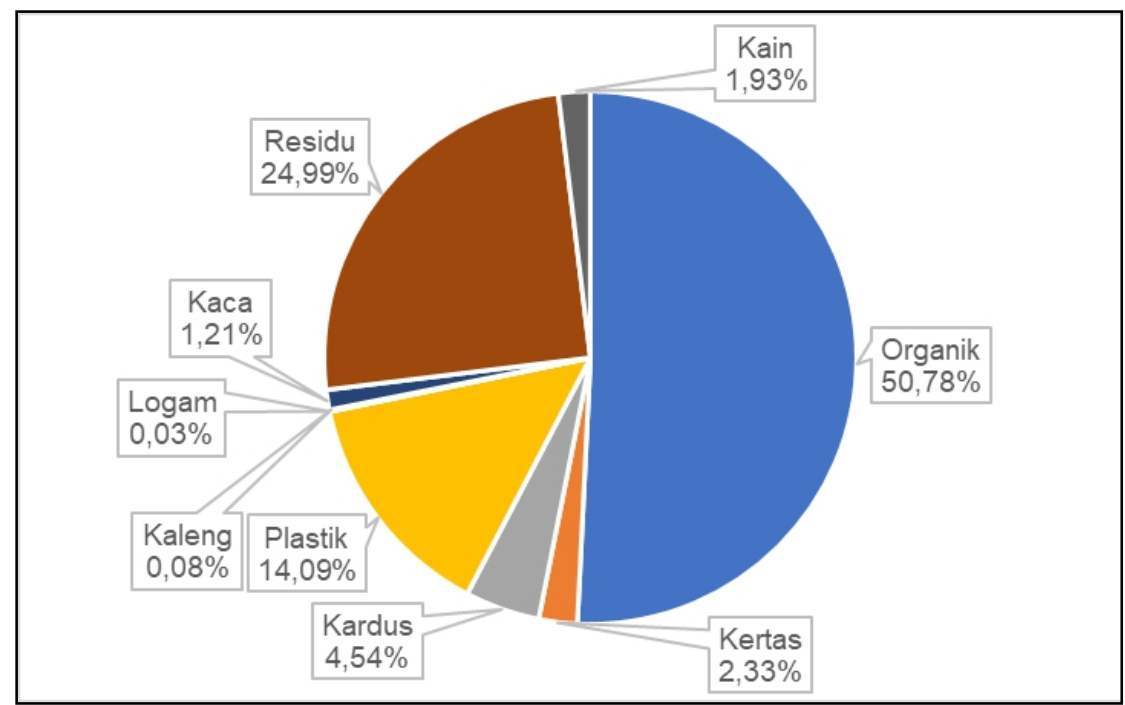

Gambar 1. Komposisi sampah di Itenas

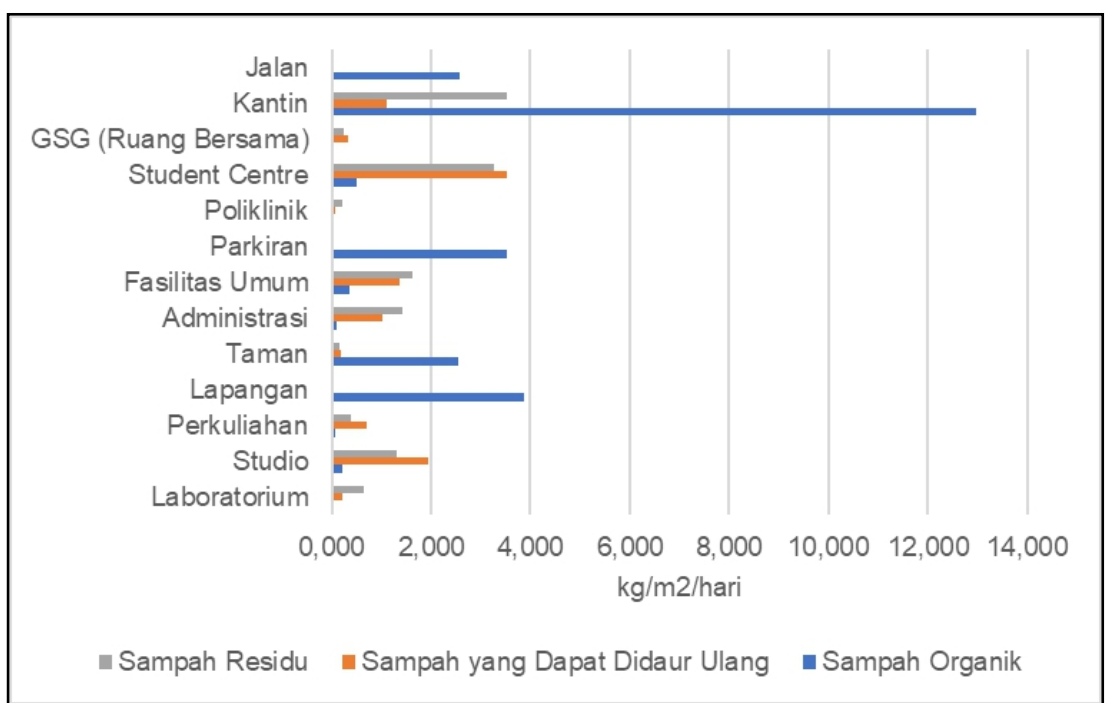

Gambar 2. Berat komposisi sampah berdasarkan luas area di Itenas 
Berdasarkan Gambar 2, terlihat bahwa kegiatan kantin menghasilkan sampah organik yang paling dominan yaitu sebesar 12,967 $\mathrm{kg} / \mathrm{m}^{2} /$ hari sedangkan kegiatan ruang bersama (GSG) paling sedikit menghasilkan sampah organik yaitu sebesar $0,038 \mathrm{~kg} / \mathrm{m}^{2} /$ hari karena sisa-sisa makanan ataupun kegiatan memasak lebih banyak dilakukan pada kegiatan kantin dibandingkan ruang bersama (GSG). Selanjutnya, kegiatan student centre (SC) menghasilkan sampah yang dapat didaur ulang yang paling dominan yaitu sebesar 3,526 $\mathrm{kg} / \mathrm{m}^{2} /$ hari sedangkan kegiatan poliklinik menghasilkan sampah yang dapat didaur ulang yang paling sedikit yaitu sebesar 0,068 $\mathrm{kg} / \mathrm{m}^{2} /$ hari karena kegiatan student centre (SC) merupakan tempat unit kegiatan mahasiswa sehingga mahasiswa banyak melakukan kegiatan termasuk menimbulkan sampah pada kegiatan student centre (SC).

\section{KESIMPULAN}

Hasil kajian timbulan dan komposisi di Institusi dengan studi kasus di Institut Teknologi Nasional Bandung (Itenas) dapat disimpulkan sebagai berikut:

1. Timbulan sampah di Itenas berdasarkan luas area kampus yaitu $0,015 \mathrm{~kg} / \mathrm{m}^{2} /$ hari dan $0,242 \mathrm{~L} / \mathrm{m}^{2} /$ hari sedangkan berdasarkan jumlah penghuni kampus yaitu 0,156 $\mathrm{kg} /$ orang/hari dan 2,48 L/orang/hari;

2. Komposisi sampah Itenas berdasarkan hasil pengelompokkan sampah yang telah ditentukan yaitu sampah organik, sampah yang dapat didaur ulang $(14,09 \%$ plastik; $4,54 \%$ kardus; $2,33 \%$ kertas; $1,93 \%$ kain; $1,21 \%$ kaca; $0,08 \%$ kaleng; dan $0,03 \%$ logam) serta sampah residu masing-masing sebesar $50,78 \% ; 24,22 \%$ dan $24,99 \%$;

3. Kegiatan kantin yang paling dominan menghasilkan sampah organik di Itenas, sedangkan kegiatan ruang bersama (GSG) yang paling sedikit menimbulkan sampah organik di Itenas;

4. Kegiatan student centre (SC) yang paling dominan menghasilkan sampah yang dapat didaur ulang sedangkan kegiatan poliklinik yang paling sedikit menghasilkan sampah yang dapat didaur ulang.

\section{PERSANTUNAN}

Penulis menyampaikan terima kasih kepada Institut Teknologi Nasional Bandung (Itenas) Jurusan Teknik Lingkungan karena telah memberikan izin dan data-data pendukung untuk melakukan penelitian di kampus serta dukungan pembiayaan dalam penulisan naskah ini.

\section{DAFTAR PUSTAKA}

1. Pemerintah Republik Indonesia. (2008). Undang-Undang Nomor 18 Tahun 2008 tentang Pengelolaan Sampah. Lembaran RI Tahun 2008 Nomor 4851. Jakarta: Sekretariat Negara.

2. Kementrian Riset, Teknologi dan Pendidikan Tinggi (DIKTI), Indonesia. (2018). Diperoleh dari

http://forlap.dikti.go.id/perguruantinggi/homegr aphpt (diakses pada 20 Januari 2020).

3. An Taisce, E. E. U. (2013). The green-campus programme.

4. Mbuligwe, S. E. (2002). Institutional Solid Waste Management Practices in Developing Countries a Case Study of Three Academic Institutions in Tanzania. Resources, Conservation and Recycling, 35(3), 131-146.

5. Seprimon, S., Aziz, R., \& Candrianto, C. (2019). Analisis Timbulan, Komposisi dan Potensi Daur Ulang Sampah di Kampus Politeknik ATI Padang. Jurnal Dampak, 16(2), 66-70.

6. Kahmeyer, M., Miller, C., Neppel, K., Ronnebaum, C., Webber, J., \& Zinke, B. (2011). Waste Characterization Study for KSU Recycling. 2011. Available at: http://www.kstate.edu/nres/capstone/Recyclin gSpring.

7. Smyth, D.P., Fredeen, A.L. and Booth, A.L. (2010) Reducing Solid Waste in Higher Education: The First Step Towards 'Greening' a University Campus. Resources, Conservation and Recycling.54: 1007-1018.

8. Taghizadeh, S., Ghassemzadeh, H. R., Vahed, M. M., \& Fellegari, R. (2012). Solid Waste Characterization and Management within University Campuses case study: University of Tabriz. Exilir Pollution, 43, 6650-6654.

9. Lingga, M. (2019). Studi Timbulan dan Komposisi Sampah Kawasan Kampus UIN ArRaniry. Banda Aceh: Universitas Islam Negeri Ar-Raniry.

10.Zhang, N., Williams, I. D., Kemp, S., \& Smith, N. F. (2011). Greening academia: Developing sustainable waste management at Higher Education Institutions. Waste management, 31(7), 1606-1616.

11. Mason, I. G., Oberender, A., \& Brooking, A. K. (2004). Source separation and potential reuse of resource residuals at a university campus. Resources, Conservation and Recycling, 40(2), 155-172. 
12. Salami, L., Susu, A. A., Patinvoh, R. J., \& Olafadehan, O. A. (2011). Characterisation study of solid wastes: a case of Lagos state. International Journal of Applied Science and Technology, 1(3).

13. Forouhar, A., \& Hristovski, K. D. (2012). Characterization of the municipal solid waste stream in Kabul, Afghanistan. Habitat International, 36(3), 406-413.

14. Kalanatarifard, A., \& Yang, G. S. (2012). Identification of the municipal solid waste characteristics and potential of plastic recovery at Bakri Landfill, Muar, Malaysia. Journal of Sustainable Development, 5(7), 11.

15. Standar Nasional Indonesia. (1994). SNI 193964-1994 tentang Metode Pengambilan dan Pengukuran Contoh Timbulan dan Komposisi Sampah Perkotaan. Jakarta: Badan Standar Nasional.
16. Standar Nasional Indonesia. (2002). SNI 192454-2002 tentang Tata Cara Teknik Operasional Pengelolaan Sampah. Jakarta: Badan Standar Nasional.

17.ASTM D5231-92. (2008). Standard Test Method for Determination of the Composition of Unprocessed Municipal Solid Waste. ASTM International.

18. Tchobanoglous, G. (1993). Integrated Solid Waste Management. New York: Mc Graw-Hill International Edition.

19. Menteri Pekerjaan Umum. (2013). Peraturan Menteri Pekerjaan Umum Republik Indonesia Nomor 03/PRT/M/2013 tentang Penyelenggaraan Prasarana dan Sarana Persampahan dalam Penanganan Sampah Rumah Tangga dan Sampah Sejenis Rumah Tangga. Jakarta: Kementerian Pekerjaan Umum. 